\title{
PROGNOSTIC FACTORS OF LYMPH NODES IN COLORECTAL CARCINOMA
}

\author{
Marilena Stoian ${ }^{1 \cdot 2}$, Lucia Indrei ${ }^{1}$, Victor Stoica ${ }^{1}$ \\ "Carol Davila" University of Medicine and Pharmacy, Bucharest \\ 2"Dr. Ion Cantacuzino" Clinical Hospital, Bucharest \\ Corresponding author: \\ Marilena Stoian \\ E-mail: marilenastoian@yahoo.com
}

\begin{abstract}
Background/Aims. The aim of this study was to establish whether, and to what extent, preand intraoperatively detected characteristics (demographic, anamnestic and laboratory data) and tumor characteristics can be used in the assessment of regional lymph node involvement in patients with colorectal carcinoma. The assessment also included the number of lymph nodes involved in patients with positive lymph nodes. Considering that the number of obtained lymph nodes is resected specimens, assessment parameters also included the percentage of the involved lymph nodes within the total population of lymph nodes.

Methodology. From 2010-2019, 46 patients with carcinoma of the rectum and sigmoid colon were studied, with a total number of 736 lymph nodes evaluated. Out of the total number of lymph nodes, 577 (78.4\%) were benign and 159 (21.6\%), malignant. Data were analyzed by multi-variant statistical methods: discriminant analysis and multiple regression.
\end{abstract}

Results. For this patient group, we evaluated the following potentially predictive factors for lymph node involvement: age; serum hemoglobin, albumin and alkaline phosphatase levels; weight loss; and the primary tumor localization characteristics: histological type, macroscopic growth pattern and depth of tumor invasion of the bowel wall. We found that there was no difference in the prediction of regional lymph node involvement between analysis of the aforementioned parameters and analysis of the isolated discriminators only.

Conclusion. A predictability likelihood of $83.78 \%$ greatly surpasses the acceptable error tolerance level of 5\%. Correlation of demographic, anamnestic and laboratory data about the patient and the characteristics of the primary tumor cannot be used in distinguishing malignant lymph nodes from benign ones. These data cannot be the basis for exact intraoperative staging and thus cannot be significant criteria foe decision-making about operative treatment modalities.

Keywords: Colorectal carcinoma, lymph nodes, prognostic. 


\section{INTERNAL}

\section{Original Papers}

\section{Rezumat}

Introducere, obiective. Scopul acestui studiu a fost de a stabili dacă și în ce măsură caracteristicile identificate pre și intraoperator (date demografice, anamnestice și de laborator) și caracteristicile tumorii pot fi utilizate pentru a evalua riscul de implicare a ganglionilor regionali la pacienții cu carcinom colorectal. La pacienții cu ganglioni limfatici pozitivi s-a evaluat, de asemenea, numărul de ganglioni limfatici afectați. Având în vedere că ganglionii analizați erau piese de rezecție, între parametrii evaluați s-a inclus și procentul de ganglioni limfatici afectați din populația totală de ganglioni limfatici.

Metodologie. Au fost studiați 46 de pacienți cu carcinom rectal și sigmoidian, în perioada 2010-2019, totalizând 736 de ganglioni limfatici evaluați. Din numărul total de ganglioni limfatici, 577 (78,4\%) au fost benigni și 159 (21,6\%), maligni. Datele au fost analizate prin metode statistice multivariate: analiză discriminantă și regresie multiplă.

Rezultate. Pentru acest grup de pacienți, am evaluat următorii factori potențial predictivi pentru implicarea ganglionilor limfatici: vârstă, hemoglobină, albumină și fosfatază alcalină; scădere ponderală; caracteristicile primare ale tumorii: tip histologic, model de creștere macroscopică și profunzimea invaziei tumorale a peretelui intestinal. Am constatat că nu a existat nicio diferență în predicția implicării ganglionilor limfatici regionali între analiza parametrilor menționați anterior și analiza discriminatorilor izolați.

Concluzie. Predictibilitatea de $83,78 \%$ depășește cu mult nivelul acceptat de toleranță la eroare de 5\%. Corelarea datelor demografice, anamnestice și de laborator privitoare la pacient și caracteristicile tumorii primare nu poate fi utilizată pentru a distinge ganglionii limfatici maligni de cei benigni. Aceste date nu pot sta la baza stadializării intraoperatorii exacte și, prin urmare, nu pot reprezenta criterii semnificative pentru luarea deciziilor cu privire la modalitățile de tratament.

Cuvinte cheie: carcinom colorectal, ganglioni limfatici, prognostic. 


\section{Introduction}

Based on the studies of Dukes, Kirklin, Astler and Coller, Jass and Harisson ${ }^{(1-7)}$, a question is imposed: it is possible, on the basis of correlation of clinical and pathological characteristics, to distinguish those pre-and intraoperatively detected clinical and pathological characteristics which influence regional lymph node involvement, as this would be of relevance for the selection of the most appropriate operative treatment? All these authors and many others agree that only a small number of patients benefit from extended lymphadenectomy. Ravitch ${ }^{(4)}$ conclude that extended lymphadenectomy would not be indicated in carcinoma without positive regional lymph nodes, which is the case in approximately $50 \%$ of cases during the intraoperative period. Grinnell ${ }^{(8)}$, Hojo ${ }^{(9)}$ and Moriya(10) came to the clinical observations that not a single patient with positive only paraaortic or positive lateral lymph nodes can survive a 5-year follow -up period. This is why we may conclude that only patients with positive intermediary lymph nodes can benefit from extensive lymphadectomy. According to Miler and Jones, these can be identified during surgery in only $10 \%$ of patients, and in $24 \%$ of patients according to Sterns ${ }^{(11)}$.

The aim of this study was to establish whether, and to what extent, pre- and intraoperatively detected characteristics (demographic, anamnestic and laboratory data) and tumor characteristics can be used in the assessment of regional lymph node involvement in patients with colorectal carcinoma.

The assessment also included the number of lymph nodes involved in patients with positive lymph nodes. Considering that the number of obtained lymph nodes is resected specimens, assessment parameters also included the percentage of the involved lymph nodes within the total population of lymph nodes.

\section{Methodology}

From 2010-2019, 46 patients with carcinoma of the rectum and sigmoid colon were selected and included in the study. These are the data collected about the patients:

- demographic: age and sex;

- anamnestic: main symptoms and symptom duration, personal and family anamnestic data;

- laboratory: blood type and count; electrolytes, serum iron, albumin and total proteins, bilirubin, glycoses, cholesterol, transaminases, alkaline phosphatase, sedimentation rate and alpha 2 globulin level);

- tumor characteristics: localization, type of growth pattern, histological type, size and presence of necrosis in the tumor. Depth of tumor invasion was noted intraoperatively, and the data were analyzed from intraoperatively protocol. Regional lymph nodes were stained by means of the classic hematoxylin and eosin technique.

Data were analyzed by multi-variant statistical methods: discriminant analysis and multiple regression.

\section{Results}

15 (32.61\%) of 46 patients were female and 31 (67.39\%) male. The youngest patient was 24 years old and the oldest 77 , while most patients were over 50 years of age. Weight loss was conspicuous in 18 patients $(39.13 \%)$, with a maximal noted weight loss of $20 \mathrm{~kg}$ and an average of $3 \mathrm{~kg}$. Tumors are 


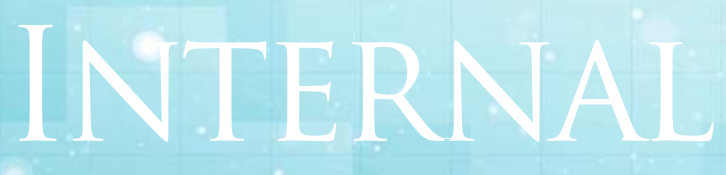

Original Papers

located in sigmoid and rectosigmoid junction in $19.56 \%$ of patients, while 28 patients $(60.88 \%)$ were located in the rectum. In $15.22 \%$ of the cases, the tumor was of a vegetant growth type, $2.17 \%$ infiltrative, $38.96 \%$ ulcero-vegetant, and $45.65 \%$ ulceroinfiltrative.

The carcinoma types were as follows: $58.70 \%$ tubular carcinoma, $32.61 \%$ mucinous, $6.52 \%$ "signet ring" and $2.77 \%$ adenosquamose carcinoma. Tumor necrosis was observed in $56.52 \%$ of the cases. In $6.52 \%$ of the cases, the tumor size was less than $2 \mathrm{~cm}$; in $39.13 \%, 2.5$ to $5 \mathrm{~cm}$; and in $54.35 \%$, over $5.5 \mathrm{~cm}$ in diameter. With regard to the depth of tumor invasion through the bowel wall, these was muscular invasion in $30.43 \%$ of the observed patients, invasion of the serosa in $58.70 \%$ and of the adjacent structures in $10.87 \%$. A total of 736 lymph nodes were identified with an average rate of 15.66 per patient. 577 (78.4\%) were benign and 159 (21.6\%) were malignant.

The analysis of distinguished patient characteristics and pre- and intraoperatively detected tumor characteristics of significance for lymph node involvement is seen in Table 1 . The aim was to discover those characteristics which significantly differed in the group with positive lymph nodes from the non-positive regional lymph nodes. The following discriminators were applied in our study: age, hemoglobin, serum albumin and alkaline phosphatase level; tumor localization; macroscopic growth type; histologic type; depth of bowel wall invasion and weight loss.

A significantly higher incidence of regional lymph node involvement was observed in the lower positioned tumors (rectum in relation to sigma) and in the ulcerous and ulcerinfiltrative growth types in relation to the vegetant, poorly differentiated histologic tumor type (there was a greater deviation from the typical glandular structures and mucine appearance) as well as in tumors with deeper bowel wall invasion.

The greatest ratability of the mentioned data was in depth of tumor penetration through the bowel wall $(p=0.0018)$ and histologic tumor type ( $p=0.0020)$, but while these data are significant, they are not highly significant. Therefore, it can be concluded that the same probability of lymph node involvement prediction of $83,78 \%$ is achieved by analysis of all the parameters and by analysis of the nine selected parameters only $(p<0.05)$.

The analysis of the effect of patient characteristics and pre- intraoperatively detected tumor characteristics on the number of involved regional lymph nodes is seen in Table 2. In our study hemoglobin level and histologic tumor type were the distinguishing discriminators: lower hemoglobin levels were noted in the patient group with the greater 


\begin{tabular}{|c|c|c|c|c|c|c|}
\hline & $\begin{array}{l}\text { Lymph } \\
\text { nodes }\end{array}$ & $n$ & $\min$ & $\max$ & $x$ & SD \\
\hline \multirow{2}{*}{ Age (years) } & Not involved & 23 & 39 & 77 & 60.93 & 13.33 \\
\hline & Involved & 24 & 24 & 77 & 56.53 & 12.79 \\
\hline \multirow{2}{*}{$\mathrm{Hb}(\mathrm{g} / \mathrm{l})$} & Not involved & 23 & 8.4 & 11.1 & 12.37 & 2.11 \\
\hline & Involved & 24 & 7.2 & 11.8 & 12.80 & 1.89 \\
\hline \multirow{2}{*}{$\begin{array}{l}\text { Serum } \\
\text { Albumin }(g / l)\end{array}$} & Not involved & 23 & 28 & 46 & 39.93 & 4.27 \\
\hline & Involved & 24 & 26 & 50 & 39.07 & 5.54 \\
\hline \multirow{2}{*}{$\begin{array}{l}\text { Alkaline } \\
\text { phosphatase } \\
\text { (mmol/l) }\end{array}$} & Not involved & 23 & 45 & 156 & 90.53 & 28.54 \\
\hline & Involved & 24 & 42 & 170 & 105.80 & 37.43 \\
\hline \multirow{2}{*}{$\begin{array}{l}\text { Weight loss } \\
(\mathrm{kg})\end{array}$} & Not involved & 23 & 2 & 17 & 2.73 & 4.13 \\
\hline & Involved & 24 & 2 & 20 & 4.93 & 7.10 \\
\hline \multirow{2}{*}{$\begin{array}{l}\text { Tumor } \\
\text { localization } \\
(\mathrm{cm})\end{array}$} & Not involved & 23 & 8 & 10 & 9.40 & 0.74 \\
\hline & Involved & 24 & 8 & 10 & 9.67 & 0.72 \\
\hline \multirow{2}{*}{$\begin{array}{l}\text { Histologic } \\
\text { type * }\end{array}$} & Not involved & 23 & 1 & 2 & 1.33 & 0.49 \\
\hline & Involved & 24 & 1 & 4 & 1.67 & 0.98 \\
\hline \multirow{2}{*}{$\begin{array}{l}\text { Growth } \\
\text { pattern } * *\end{array}$} & Not involved & 23 & 1 & 5 & 3.40 & 1.55 \\
\hline & Involved & 24 & 1 & 5 & 4.33 & 0.61 \\
\hline \multirow{2}{*}{$\begin{array}{l}\text { Depth of } \\
\text { invasion (pT) }\end{array}$} & Not involved & 23 & $\mathrm{~T} 2$ & T4 & 2.647 & 0.72 \\
\hline & Involved & 24 & $\mathrm{~T} 2$ & $\mathrm{~T} 4$ & 3.40 & 0.51 \\
\hline
\end{tabular}

*1: Adenocarcinoma, 2: Carcinoma mucinosum, 3: Signet ring cell carcinoma, 4: Carcinoma adenosquamosum **1: Vegetant, 2: Ulcero-vegetant, 3: Ulcerous, 4: Infiltrative,5: Ulceroinfiltrative

Table 1. Discrimant Analysis Distinguished Patient Characteristics and Pre-and Intraoperatively Detected Tumor Characteristics of Significance for Lymph Node Involvement

\begin{tabular}{|l|l|l|l|}
\hline Variable & $\begin{array}{l}\text { Regression } \\
\text { coefficient }\end{array}$ & t-test & $\mathbf{p}$ \\
\hline Histologic type & 4.9455 & 7.009 & 0.0009 \\
\hline Hg level & -0.9347 & -2.697 & 0.0430 \\
\hline Constant & 5.6217 & 1.208 & 0.2809 \\
\hline
\end{tabular}

Table 2. Regression Analysis of Characteristics of Patients with Pre-and Intraoperatively Detected Tumor Characteristics of Significance for the Number of Involved Lymph Nodes 


\section{INTEF}

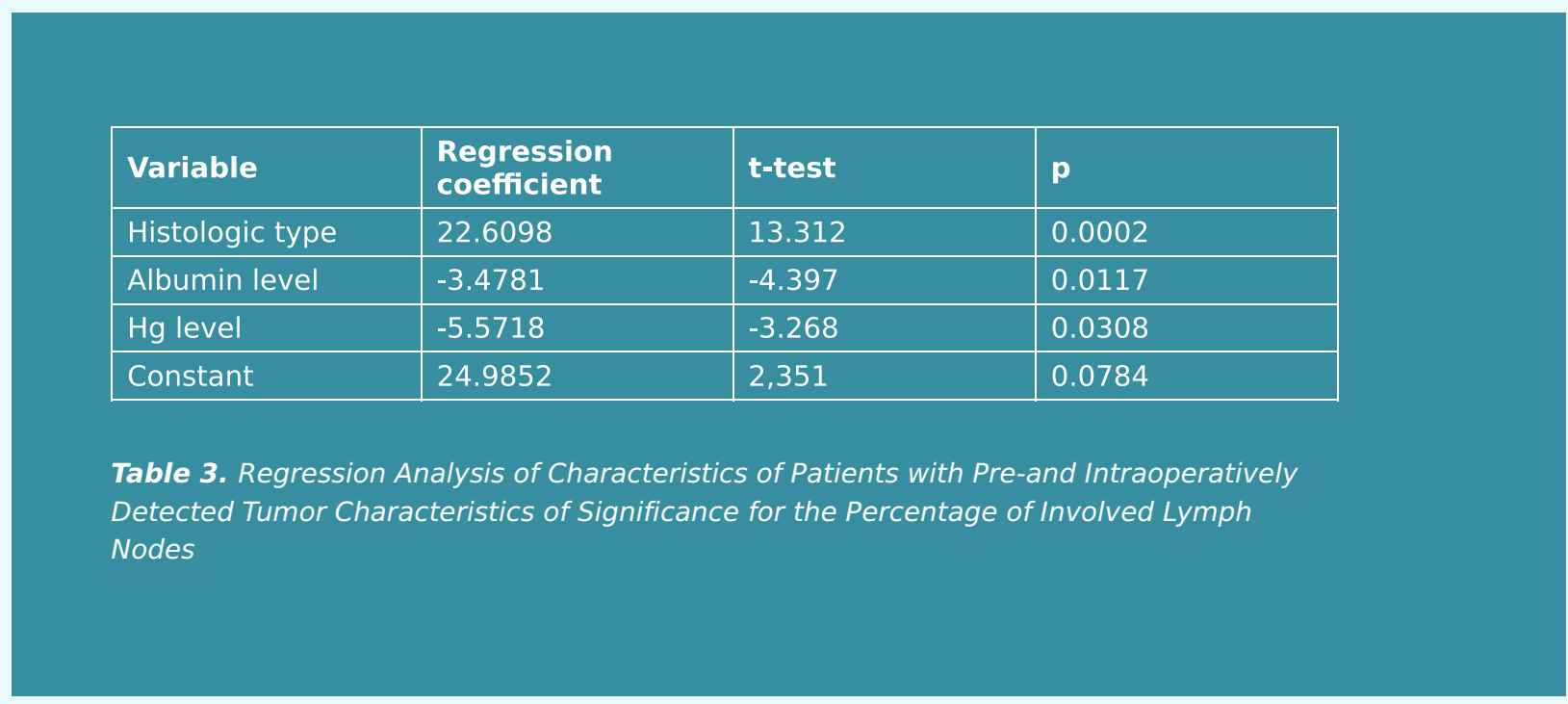

number of involved regional lymph nodes noted in the ulcerous and ulcer-infiltrative growth patterns than in the vegetative tumor growth pattern (Table 2).

The analysis of the effect of patient characteristics and pre- intraoperatively detected tumor characteristics on the percentage of involved regional lymph nodes is seen in Table 3 Hemoglobin and serum globulin levels and the histologic tumor type were distinguishing discriminators: lower hemoglobin and serum globulin levels were noted in the patient group with the greater number of involved regional lymph nodes; also there was a larger number of involved regional lymph nodes noted in the ulcerous and ulcerinfiltrative growth patterns than in the vegetative tumor growth pattern (Table 3 ).

\section{Discussion}

Demographic data relieved that the likelihood of regional lymph node involvement was greater in patients in their sixties than those in their seventies because of the greater tissue regenerates ability of this age, which implies an increased malignant potentiality, also. Dukes found that older patients in general are inflicted by tumors of lower histologic grades ${ }^{(11,12)}$.

Increased alkaline phosphatase levels in the patient group with tumor -involved lymph nodes positively corelated with the presence of distant metastasis, which was diagnosed either pre-, intraoperatively, or in the early postoperative period. The hemoglobin level was lower in patients without regional lymph node involvement. Most authors agree that 
blood loss, as the first symptom of the disease, is prognostically much more reliable than obstruction or perforation. In a series of 267 patients, Thomas found that $54 \%$ of patients with blood loss as the initial symptom, $28 \%$ of patients with obstruction and only $11 \%$ of patients with perforation as the initial symptom survived the 5-year follow-up period ${ }^{(11,13)}$.

There is a greater probability of regional lymph node involvement in lower positioned tumors (rectal in relation to those of the sigmoid colon). Since the rectal ampoule acts as a reservoir, the symptomatology takes longer to present ${ }^{(5)}$. Of all the data, the highest reliability was associated with the depth of tumor invasion into the bowel wall and the histologic tumor type. HerreraOrnelas have argued that the depth of tumor invasion through the bowel wall has no effect on the likelihood of assessment of regional lymph node involvement ${ }^{(14)}$.

Contrary the greatest number of pathologists are of the opinion that advanced tumor invasion through the bowel wall increases the likelihood of regional lymph node involvement, with coincide with our series ${ }^{(2,6}$, ${ }^{7,9)}$. In our series, the depth of tumor spread through the bowel wall, i.e. the presence of extramural expansion, was detected both macroscopically and histologically. In tumors which have penetrated all layers of the bowel wall, involvement of the regional lymph nodes is the expected occurrence, while almost $30 \%$ of small lymph nodes are malignant. In tumors which have not penetrated through the bowel wall, malignant lymph nodes are rarely found ( $1.9 \%$ incidence), and those that have been found were located in the palpability limit (approx. $5 \mathrm{~mm}$ in size and focally involved).

As previously stated, local aggression is primarily conditioned by the grade of differentiation rather than by the size of the area involved. Hojo. Gilchrist et al. have argued that histologic tumor type affects the likelihood of assessment of regional lymph node involvement ${ }^{(9)}$. Authors as Bacon, Symonds and Vickery have argued that the presence of mucine is a prognostically poor sign in colonic carcinoma, especially in rectum carcinoma ${ }^{\left(11,{ }^{15)}\right.}$. In our study, the appearance of mucine, particularly of the squamosa component, correlated with a significantly larger number of involved lymph nodes.

\section{Conclusion}

There is a great amount of data about the number of involved lymph nodes and the percentage of tumor involved lymph nodes in the total lymph node population, as well as the significance of the histologic tumor type in relation to plasma hemoglobin and albumin levels. Considering the fact that preoperatively detected data about the patient and the primary tumor, as well as the intraoperative assessment of the depth of tumor invasion through the bowel wall are not reliable parameters for assessment of regional lymph node involvement, they cannot be the basis for exact intraoperative staging. These criteria thus cannot be of significance in the decision-making process for operative treatment.

\section{References}

1. Beahrs O. Colorectal cancer staging as a prognostic feature. Cancer 1982; 50:2615-17.

2. Fenoglio-Preiser CM.Gastrointestinal Patology , New York: Raven Press. 1989:745-86.

3. Fielding P, Chapius P.Clinicopathological staging for colorectal cancer: An international comprehensive anatomical terminology ( ICAT). World congress of gastroenterology 1990; Working party reports 57-62.

4. Ravitch M. Malignant tumors of the rectum. Current problems in surgery. 1975; 9:757-801. 


\section{INTERNAI Original Papers}

5. Schwartz SI, Ellis H. Maingot s abdominal operations. Appleton-Century-Crofts 1985;1361-535.

6. Jass JR, Morson BC. Reporting colorectal cancer. J Clin Pathol 1987; 40:1016-23.

7. Harrison J, Dean PJ, El-Zeky F, Zwaag RV.From Dukes through Jass: pathologic indicators in rectal cancer. Human pathology 1994; 25: 1498-1505.

8. Grinnel R, Hiatt R. Ligation of the inferior mesenteric artery at the aorta in resection for carcinoma of the sigmoid and rectum. Surg Gynecol Obstr 1952; 94:526-34. 9. Hojo K, Koyama Y, MoryaY. Lymfatic spread and its prognostic values in patients with rectal cancer.Am J Surg 1982; 144:350-4.

10. MoryaY, Hojo $K$, et al. Significance of lateral node dissection for advanced rectal carcinoma at or below the peritoneal reflection. Dis Colon Rectum 1989:307-315.
11. Sugarbaker PH. Carcinoma of the colon. Prognosis and operative choice. Curr Prob Surg 1981; 18: 791.

12.Block GE, Enker WE.Survival after operations for rectal carcinoma in patients after 70 years of age.Ann Surg 1991; 174:521-7.

13. Thomas WH, Larson RA, Wright HK, Cleveland JC.An analysis of patients with carcinoma of the right colon. Surg Gynecol Obstet 1998; 127:313-18.

14. Herrera-Ornelas L, Villareal RV. Incidence of metaststases from rectal adenocarcinoma in small lymph nodes detected by a clearing technique.Dis Colon Rectum 1992; 35:783-87

15. Bacon HE, Dirbas F. Extensive lymphadenectomy and high ligation of the inferior mesenteric artery for carcinoma of the left colon and rectum. Dis Colon Tectum1998; 1: 457-65. 